Full length article

\title{
Impacts of pineapple peel powder on growth performance, innate immunity, disease resistance, and relative immune gene expression of Nile tilapia, Oreochromis niloticus
}

\author{
Hien Van Doan ${ }^{\text {a,b, }}$, Seyed Hossein Hoseinifar ${ }^{c}$, Ramasamy Harikrishnan ${ }^{\text {d }}$, Trisadee Khamlor ${ }^{\text {a }}$, \\ Montri Punyatong ${ }^{a}$, Wanaporn Tapingkae ${ }^{a}$, Morteza Yousefi ${ }^{\mathrm{e}}$, Jorge Palma ${ }^{\mathrm{f}}$, Ehab El-Haroun ${ }^{\mathrm{g}}$ \\ ${ }^{a}$ Department of Animal and Aquatic Sciences, Faculty of Agriculture, Chiang Mai University, Chiang Mai, 50200, Thailand \\ ${ }^{\mathrm{b}}$ Innovative Agriculture Research Center, Faculty of Agriculture, Chiang Mai University, Chiang Mai, 50200, Thailand \\ ${ }^{\mathrm{c}}$ Department of Fisheries, Gorgan University of Agricultural Sciences and Natural Resources, Gorgan, Iran \\ d Department of Zoology, Pachaiyappa's College for Men, Kanchipuram, 631 501, Tamil Nadu, India \\ e Department of Veterinary Medicine, Peoples' Friendship University of Russia (RUDN University), 6 Miklukho-Maklaya St, Moscow, 117198, Russian Federation \\ ${ }^{\mathrm{f}}$ CCMAR, Universidad Do Algarve, FCT, Edificio 7, Campus de Gambelas, Faro, Portugal \\ ${ }^{\mathrm{g}}$ Fish Nutrition Research Laboratory, Animal Production Department, Faculty of Agriculture, Cairo University, Cairo, Egypt
}

\section{A R T I C L E I N F O}

\section{Keywords:}

Pineapple peels

Biofloc

Nile tilapia

Mucosal immune

Gene expression

\begin{abstract}
A B S T R A C T
An 8-week growth trial was conducted to examine the efficacy of pineapple peel powder (PAPP) on growth rate and immunity of Nile tilapia, $O$. niloticus. Three hundred Nile tilapia $(20.91 \pm 0.11 \mathrm{~g}$ ) were fed five diets containing different levels of PAPP at $0,10,20,30$ and $40 \mathrm{~g} \mathrm{~kg}^{-1}$ PAPP, respectively. After four and eight weeks of the feeding trial, growth rates, and immune responses were tested. A challenge test using Streptococcus agalactiae and relative immune gene expression were performed after eight weeks of PAPP feeding. It was found that skin mucus and serum lysozyme, skin mucus and serum peroxidase, alternative complement, phagocytosis, and respiratory burst activities were significantly increased with the addition of PAPP. The maximum $(P \leq 0.05)$ innate immune values were noted in fish fed $10 \mathrm{~g} \mathrm{~kg}^{-1}$ PAPP. Similarly, the up-regulation of $I L 1, I L 8$, and $L B P$ gene expressions were also detected in fish fed PAPP diets, with the maximum value was found in $10 \mathrm{~g} \mathrm{~kg}^{-1} \mathrm{PAPP}$ fed fish. The relative percentage of survival (RPS) of Oreochromis niloticus after the challenge test were (56.00\%, $72.00 \%, 60.00 \%$, and $44.00 \%$ ) for the 5, 10, 20 and $40 \mathrm{~g} \mathrm{~kg}^{-1}$ PAPP diets, respectively. Fish fed the $10 \mathrm{~g} \mathrm{~kg}^{-1}$ PAPP supplemented diet achieved the highest $(P<0.05)$ survival rate against $S$. agalactiae. Growth and feed efficiency were outstandingly $(P<0.05)$ enhanced in the PAPP groups. In conclusion, PAPP can be potentially used as a feed additive in Nile tilapia culture under Biofloc system.
\end{abstract}

\section{Introduction}

Aquaculture represents a major role in securing the increasing demands for animal protein for human consumption [1,2]. Today, aquaculture represents approximately fifty percent of globalized fishery production and has been accountable for the prominent growth of protein sources [3]. Tilapia is commonly cultivated fish worldwide; due to its rapid growth, acclimation, and high returns [4]. Nevertheless, the intensification and enlargement of fish farming have resulted in a negative effect on water quality, as well as an increased risk of pathogen infection and disease outbreak [5], leading to a reduction of the survival rate of farmed fish [6]. Excessive use of antibiotics and chemotherapeutics compounds have resulted in the development of antimicrobial-resistant bacteria and accumulated antibiotic residues in farm water and fish tissues, that causes environmental intimidation and alters the microflora arrangement $[7,8]$. Therefore, searching for safe compounds to manage pathogen microbe infection in aquaculture is needed.

Feed costs represent approximately $80 \%$ of total operating costs in aquaculture [9]. To maximize net profits, and enhance growth and immune system, we must minimize feed costs and control disease infection. Through the use of agro-industrial by-products, we can produce high-quality aquafeed and reduce waste output [10], thereby reaching a "zero waste" outcome in both livestock and aquaculture diets $[11,12]$.

\footnotetext{
* Corresponding author. Department of Animal and Aquatic Sciences, Faculty of Agriculture, Chiang Mai University, Chiang Mai, 50200, Thailand.

E-mail address: hien.d@cmu.ac.th (H. Van Doan).
} 
Among them, the use of pineapple peel, explored herein, is a viable choice. The global production of pineapple increased to 27 million metric tons in 2017 [13]. Pineapple peel accounts for 29 to $42 \%$ of the total weight of the fruit [13], yet is only seldom used for fertilization or compost, or it is simply discarded [14]. However, pineapple by-products contain insoluble fibres, sugars, pectin, proteins, micronutrients, and polyphenols ingredients [15-17]; and are an abundant source of bromelain, a costly blend of proteolytic enzymes with various biological functions in the pharmaceutical, food, and cosmetic sectors [18]. There are also extensive therapeutic benefits, due to the cytotoxic, antidiabetic, antihyperlipidemic, and antioxidant properties present [19-21]. Therefore, consideration as a functional feed additive in aquaculture is appropriate.

Biofloc is another aspect of environmentally friendly and sustainable aquaculture [22]. Biofloc technology is a protocol that combines microorganisms and other organic materials be accessible as fish feed [22-24]. The addition of feed additives to the biofloc reproduce a microorganism community in both the water and fish gut capable of restraining pathogenic strains [25-28]. To date, we are not aware of any past research on the inclusion of pineapple peel powder (PAPP) in Nile tilapia diet cultures within biofloc system. The objectives of the current research, therefore, were to examine the impacts of PAPP on immune parameters and gene expressions; as well as challenging the fish with Streptococcus agalactiae, and the growth of Oreochromis niloticus in the biofloc system.

\section{Materials and methods}

\subsection{Pineapple peel powder preparation}

Fresh pineapple fruit was obtained from a private farm at Chiang Mai, Thailand. Pineapple peel was collected dried at $60^{\circ} \mathrm{C}$ for two days. After the dried process, peels were ground using a hammermill, filtered with a sieve (100-mesh) to obtain a powdered form of pineapple peel powder (PAPP), then stored for future use.

\subsection{Diets preparation}

Five experimental diets (isonitrogenous and isocaloric) were prepared according to the nutrient requirements of this species NRC [29]. The diets (1-5) were supplemented with $0,10,20,30$, and $40 \mathrm{~g}$ PAPP $\mathrm{kg}^{-1}$, respectively (Table 1). Diets was made following Doan, Hoseinifar, Jaturasitha, Dawood and Harikrishnan [30], then stored in plastic bags at $4^{\circ} \mathrm{C}$ for future use.

\subsection{Fish culture setup}

Nile tilapia were collected from the Chiang Mai Pathana Farm Co., Ltd, Chiang Mai, Thailand. To minimize stress, experimental fish were stocked in a cage after arrival and fed commercial feed for two months. At the beginning of the trial, 20 fish were selected randomly for a health examination. Three hundred fingerlings ( $20.91 \pm 0.11 \mathrm{~g}$ ) were randomly dispersed into 15 tanks ( 20 fish $\operatorname{tank}^{-1}$ ). The experimental fish in each replicate were hand-fed their respective diets ad libitum, at 9.00 a.m. and 5.00 p.m. daily for eight weeks. Starch was used with a C:N ratio of 15:1 to maintain flocs volume [31]. Water quality criteria were monitored daily, and optimum ranges for Nile tilapia were recorded. The records were $27.5 \pm 0.8^{\circ} \mathrm{C}$ for water temperature, $7.79 \pm 0.15$ for $\mathrm{pH}$, and $5 \mathrm{mg}$ $\mathrm{L}^{-1}$ for DO. Total ammonia-nitrogen (TAN), was $0.02 \mathrm{mg} \mathrm{L}^{-1}$ throughout the experiment. Biofloc volume (BFV) was determined, according to Avnimelech and Kochba [31].

\subsection{Growth parameters}

The fish fasted for $24 \mathrm{~h}$ and bulk weight at weeks 4 and 8 postfeeding were assessed according to our previous study [32].
Table 1

The formulation and proximate compositions of experimental diet $\left(\mathrm{g} \mathrm{kg}^{-1}\right)$.

\begin{tabular}{|c|c|c|c|c|c|}
\hline \multirow[t]{2}{*}{ Ingredients } & \multicolumn{4}{|c|}{ Diets $\left(\mathrm{g} \mathrm{kg}^{-1}\right)$} & \multirow[b]{2}{*}{ Diet 5} \\
\hline & Diet 1 & Diet 2 & Diet 3 & Diet 4 & \\
\hline Fish meal & 150 & 150 & 150 & 150 & 150 \\
\hline Corn meal & 200 & 200 & 200 & 200 & 200 \\
\hline Soybean meal & 390 & 390 & 390 & 390 & 378 \\
\hline Wheat flour & 70 & 70 & 70 & 70 & 70 \\
\hline Rice bran & 150 & 150 & 150 & 145 & 142 \\
\hline $\mathrm{PPP}^{\mathrm{a}}$ & 0 & 5 & 10 & 20 & 40 \\
\hline Cellulose & 20 & 15 & 10 & 5 & 0 \\
\hline Soybean oil & 5 & 5 & 5 & 5 & 5 \\
\hline Premix ${ }^{\mathrm{b}}$ & 10 & 10 & 10 & 10 & 10 \\
\hline Vitamin $C^{c}$ & 5 & 5 & 5 & 5 & 5 \\
\hline \multicolumn{6}{|c|}{ Proximate composition of the experimental diets ( $\mathrm{g} \mathrm{kg}^{-1}$ dry matter basis) } \\
\hline Crude protein & 302.28 & 302.62 & 302.95 & 303.21 & 303.32 \\
\hline Crude lipid & 61.38 & 61.44 & 61.50 & 60.94 & 59.15 \\
\hline Fibre & 60.61 & 63.50 & 66.39 & 68.50 & 70.07 \\
\hline Ash & 88.17 & 87.41 & 86.65 & 85.44 & 83.34 \\
\hline Dry matter & 991.49 & 991.51 & 991.50 & 991.56 & 991.64 \\
\hline $\mathrm{GE}(\mathrm{cal} / \mathrm{g})^{4}$ & 4,009 & 4,002 & 3,979 & 3,946 & 3,878 \\
\hline
\end{tabular}

${ }^{\text {a }}$ PPP = Pineapple peel powder.

b Vitamin and trace mineral mix supplemented as follows (IU kg ${ }^{-1}$ or $\mathrm{g} \mathrm{kg}^{-1}$ diet): retinyl acetate 1,085,000 IU; cholecalciferol 217,000 IU; D, L-a-tocopherol acetate $0.5 \mathrm{~g}$; thiamin nitrate $0.5 \mathrm{~g}$; pyridoxine hydrochloride $0.5 \mathrm{~g}$; niacin $3 \mathrm{~g}$; folic $0.05 \mathrm{~g}$; cyanocobalamin $10 \mathrm{~g}$; Ca pantothenate $1 \mathrm{~g} \mathrm{~kg}^{-1}$; inositol $0.5 \mathrm{~g}$; zinc $1 \mathrm{~g}$; copper $0.25 \mathrm{~g}$; manganese $1.32 \mathrm{~g}$; iodine $0.05 \mathrm{~g}$; sodium $7.85 \mathrm{~g}$.

${ }^{c}$ Vitamin C 98\% $5 \mathrm{~g}$.

Parameters of growth performance and feed utilization were calculated based on the following formulae:

Weight gain $(\mathrm{g})=\mathrm{W}_{2}-\mathrm{W}_{1}$;

Specific growth rate $(\mathrm{SGR} ; \% \mathrm{~g} /$ day $)=100\left[\mathrm{Ln} \mathrm{W}_{2}(\mathrm{~g})-\mathrm{Ln} \mathrm{W}_{1}(\mathrm{~g})\right] / \mathrm{T}$; where $\mathrm{W}_{2}$ is final weight $(\mathrm{g}), \mathrm{W}_{1}$ is initial weight $(\mathrm{g})$, and $\mathrm{T}$ is the experimental period (day);

Feed intake $(\mathrm{g}$ feed/fish $)=$ the summation of a diet offered to fish throughout the experiment/fish number;

Feed conversion ratio $(\mathrm{FCR})=$ feed intake/weight gain;

Fish survival $(\%)=100$ (fish number at final/fish number at initial).

\subsection{Samples collection and immunological assays}

\subsubsection{Skin mucus}

Mucus samples were collected from each treatment (three fish per group). Fish were anesthetized with clove oil and smoothly massaged in a bag containing $50 \mathrm{mM} \mathrm{NaCl}$. Subsequently, a sterile tube was used to centrifuge the solution at $1500 \mathrm{~g}$ at $4{ }^{\circ} \mathrm{C}$ for ten minutes. Afterward, supernatant $(500 \mu \mathrm{L})$ was collected and kept in a freezer for further analysis.

\subsubsection{Serum collection}

Clove oil was used to sedate the fish, and samples of blood were collected from the caudal vein using a sterile syringe $(1 \mathrm{~mL})$ as described by Van Doan, Hoseinifar, Chitmanat, Jaturasitha, Paolucci, Ashouri, Dawood and Esteban [32]. Briefly, blood (1 mL) was collected via the caudal vein of each fish using a $1 \mathrm{~mL}$ syringe and immediately released into $1.5 \mathrm{~mL}$ Eppendorf tubes without anticoagulant. The blood samples were then led to clot at room temperature for one hour, and stored in a refrigerator $\left(4^{\circ} \mathrm{C}\right)$ for four hours. After that, the samples were centrifuged at $1500 \mathrm{~g}$ for five minutes at $4{ }^{\circ} \mathrm{C}$, and the anticipated serum was gathered using a micro-pipette and stored at $-80{ }^{\circ} \mathrm{C}$ for further evaluation. 


\subsubsection{Leukocytes isolation}

One $\mathrm{mL}$ of blood was collected to obtain the leukocytes cells needed to measure the phagocytic and respiratory burst activities, as described by Chung and Secombes [33]. Briefly, one milliliter of blood was withdrawn from each fish, at a rate of three fish per replication, and then transferred into $15 \mathrm{~mL}$ tubes containing $2 \mathrm{~mL}$ of RPMI 1640 (Gibthai). This mixture was then carefully inserted into $15 \mathrm{~mL}$ tubes, containing 3 $\mathrm{mL}$ of Histopaque (Sigma, St. Louis, MO, USA). These tubes were then centrifuged at $400 \mathrm{~g}$ for 30 minutes at room temperature. Upon completion, a buffy coat of leucocytes cells drifted to the top of the Histopaque was carefully collected using a Pasteur pipette, and released into sanitized $15 \mathrm{~mL}$ tubes. After which, $6 \mathrm{~mL}$ of phosphate buffer solution (PBS: Sigma-Aldrich, USA) was added to each tube and gently aspirated. The cells in these tubes were washed twice by centrifugation at $250 \mathrm{~g}$ for ten minutes at room temperature to remove any residual Histopaque. The cells obtained were then re-suspended in the PBS and adjusted to the numbers of cells required to evaluate phagocytic and respiratory burst activities.

\subsubsection{Activities of lysozyme in the serum and skin mucus}

Lysozyme activity was measured according to Parry, Chandan and Shahani [34] with slight modification [35]. Briefly, $25 \mu \mathrm{L}$ of undiluted serum and $100 \mu \mathrm{L}$ of skin mucus from each fish was loaded into 96-well plates in triplication. Micrococcus lysodeikticus (175 $\mu \mathrm{L}, 0.3 \mathrm{mg} \mathrm{mL}^{-1}$ in $0.1 \mathrm{M}$ citrate phosphate buffer, $\mathrm{pH}$ 5.8) was then added to each well. The contents were rapidly mixed, and any changes in turbidity were measured every 30 seconds, for five minutes, at $540 \mathrm{~nm}, 25^{\circ} \mathrm{C}$, via a microplate reader. The sample's equivalent unit of activity was determined and compared with the standard curve, which was generated from the reduction of OD value $v s$. the concentration of hen egg-white lysozyme ranging from 0 to $20 \mu \mathrm{mL}^{-1}$ (Sigma Aldrich, USA), and expressed as $\mu \mathrm{g} \mathrm{mL}^{-1}$ serum.

\subsubsection{Peroxidase, ACH50, phagocytic, and respiratory activity}

The peroxidase activity in serum and skin mucus were measured according to the protocol established by Cordero, Cuesta, Meseguer and Esteban [36]. Briefly, $5 \mu \mathrm{L}$ of undiluted serum or skin mucus from each fish was placed in 96-flat-bottomed-well plates, in triplicate. Then, $45 \mu 1$ of Hank's Balanced Salt Solution (without $\mathrm{Ca}^{+2}$ or $\mathrm{Mg}^{+2}$ ) was added to each well. Afterward, $100 \mu \mathrm{L}$ of solution ( $40 \mathrm{ml}$ of distilled water $+10 \mu \mathrm{L}$ of $\mathrm{H}_{2} \mathrm{O}_{2}, 30 \%$; Sigma Aldrich + one pill of 3,3',5,5'-tetramethylbenzidine, TMB; Sigma Aldrich) was then added to each well. When the reaction color turned blue, after $30-60$ seconds, a $50 \mu \mathrm{L}$ solution of $2 \mathrm{M}$ $\mathrm{H}_{2} \mathrm{SO}_{4}$ was immediately added to each well. The optical density was then read at $450 \mathrm{~nm}$ via a microplate reader (Synergy H1, BioTek, USA). Samples not containing serum or skin mucus were considered to be blanks. A single unit was defined as the amount which produces an absorbance change, expressed as units (U) $\mathrm{mL}^{-1}$ of serum or mucus through the following equation: Peroxidase activity $=$ [absorbance of the sample] - [absorbance of blank (containing all solution without serum or mucus sample)].

ACH50 was measured according to Yano [37]. Briefly, rabbit red blood cells (R-RBC) were washed twice with PBS by centrifugation at $3000 \mathrm{rpm}$, with a $0.01 \mathrm{M}$ ethylene glycol tetra-acetic acid-magnesium-gelatin veronal buffer (0.01M - EGTA-Mg-GVB). The R-RBC concentration was adjusted to $2 \times 10^{8}$ cells $\mathrm{mL}^{-1}$ in the $0.01 \mathrm{M}-$ EGTA-Mg-GVB buffer. Then, $100 \mu \mathrm{L}$ of the R-RBC suspension was lysed with $3.4 \mathrm{~mL}$ of distilled water. The hemolysate absorbance was measured at $414 \mathrm{~nm} v s$. distilled water as a blank, and adjusted to reach 0.740. For the ACH50 test, $100 \mu \mathrm{L}$ of serum was diluted with $400 \mu \mathrm{L}$ of 0.01M-EGTA-Mg-GVB, and serial two-fold dilution was conducted. The tubes were placed on ice to retard the reaction of complement until all tubes were prepared. Consequently, $100 \mu \mathrm{L}$ of R-RBC suspension was loaded into each tube and incubated at $20{ }^{\circ} \mathrm{C}$ for 1.5 hours with occasional shaking. After incubation, $3.15 \mathrm{~mL}$ of cold saline solution $(0.85 \%$ $\mathrm{NaCl}$ ) was placed into each tube to stop the reaction. The tube was centrifuged at $1600 \mathrm{~g}$ for 5 minutes. After centrifugation, $100 \mu \mathrm{L}$ of supernatant in each dilution was loaded into 96-well plate and read at $414 \mathrm{~nm}$. The degree of hemolysis was calculated by dividing the corrected absorbance 414 value by the corrected absorbance 414 of the $100 \%$ hemolysis control. The degree of hemolysis and the serum volume were plotted on a log-log paper. The volume of serum that gave $50 \%$ hemolysis was used for calculating the ACH50 using the formula: ACH50 (units $/ \mathrm{ml}$ ) $=1 / \mathrm{K} \mathrm{x} \mathrm{r} \mathrm{x} 1 / 2$. Where $\mathrm{K}$ is the amount of serum giving $50 \%$ hemolysis, $r$ is the reciprocal of the serum dilution, and $1 / 2$ is the correction factor. The assay was performed on a $1 / 2$ scale of the original method.

Phagocytic activity was determined using the protocol of Yoshida and Kitao [38], with slight modification [39]. Briefly, $200 \mu \mathrm{L}$ of leucocyte cell suspensions $\left(2 \times 10^{6}\right.$ cells $\left.\mathrm{mL}^{-1}\right)$ were loaded on coverslips and incubated at room temperature for two hours. After incubation, the coverslips were washed with $3 \mathrm{~mL}$ of RPMI-1640 to remove any non-adherent cells. Then, a solution of $200 \mu \mathrm{L}$ of fluorescence latex beads with a concentration of $2 \times 10^{7}$ of beads $\left(\mathrm{mL}^{-1}\right.$ ) (Sigma-Aldrich, USA) was placed into each coverslip and incubated again at room temperature for 1.5 hours. The coverslips were then rewashed with $3 \mathrm{~mL}$ of RPMI- 1640 to remove any non-phagocytized bead. After washing, the coverslips were then fixed with methanol, and stained with Diff-Quik staining dye (Sigma-Aldrich, USA) for ten seconds. After staining, a wash of PBS ( $\mathrm{pH}$ 7.4) removed any excessive stains. The washed coverslips were allowed to dry at room temperature and then attached to the slides with Permount (Merck, Germany). The number of phagocyte cells per 300 adhered cells was later counted microscopically. The phagocytic index (PI) and phagocytic rate (PR\%) were calculated through the following equations: $\mathrm{PI}=$ (Number of phagocytized beads divided by the number of phagocytizing leukocytes) $* 100$.

Respiratory burst activity measured as described by Secombes [40] with minor changes [39]. Briefly, $175 \mu \mathrm{L}$ PBS cell suspension at a concentration of $6 \times 10^{6}$ cells $\mathrm{mL}^{-1}$ was loaded into the 96 well plates in triplication. Then, $25 \mu \mathrm{L}$ of nitro blue tetrazolium (NBT) at a concentration of $1 \mathrm{mg} \mathrm{mL}^{-1}$ was added to each well and incubated the solution for two hours at room temperature. Later, the supernatant was carefully discarded from each well, and $125 \mu \mathrm{L}$ of $100 \%$ methanol was then added into each well for five minutes to fix the cells. After that, $125 \mu \mathrm{L}$ of $70 \%$ methanol well ${ }^{-1}$ were added into each well, twice, for clean-up. The plates were then dried for thirty minutes at room temperature. Then, $125 \mu \mathrm{L}$ of $2 \mathrm{~N} \mathrm{KOH}$ and $150 \mu \mathrm{L}$ of DMSO were added to each well. Afterward, the plates were measured at $655 \mathrm{~nm}$ via microplate-reader (Synergy H1, BioTek, USA), according to the following: Spontaneous $\mathrm{O}^{2-}$ production $=$ (absorbance NBT reduction of the sample) - [absorbance of blank (containing $125 \mu \mathrm{L}$ of $2 \mathrm{~N} \mathrm{KOH}$ and $150 \mu \mathrm{L}$ with no leucocytes)].

\subsection{Gene expression analysis}

Relative gene expression was analysed in three fish per treatment using quantitative real-time PCR (qRT-PCR). Total RNA was extracted from $0.5 \mathrm{~g}$ of the Nile tilapia's liver samples using TRIzol Reagent (Life Technologies). The quantified and purity of the RNA were assessed by spectrophotometer (NanoDrop one, Thermo Scientific, Wilmington, USA) at 260:280 nm. The total RNA, $8 \mu \mathrm{L}$ (concentration of $1 \mu \mathrm{g} / \mu \mathrm{L}$ ), were reverse-transcribed to generate first-strand Complementary DNA (cDNA) using Master mix 1 ( $1 \mu \mathrm{L}$ of RQ1 DNase 10x reaction Buffer, $1 \mu \mathrm{L}$ of RQ1 RNAse free DNase, and $1 \mu \mathrm{L}$ of RQ1 DNase stop solution - Invitrogen), then Master mix 2 [(1 $\mu \mathrm{L}$ of Oligo dT and $1 \mu \mathrm{L}$ of DNTP's (Deoxynucleotide Mix - Aldrich Sigma)), and finally with Master mix 3 [( $4 \mu \mathrm{L}$ of buffer $5 \mathrm{x}$ ( $5 \mathrm{x}$ SSI V Buffer), $1 \mu \mathrm{L}$ of DTT, $1 \mu \mathrm{L}$ of DEPC water, and $1 \mu \mathrm{L}$ of SuperScript IV (SuperScript ${ }^{\circledR}$ IV Reverse Transcriptase) Invitrogen)]. Candidate genes (Table 2) were chosen for qRT-PCR analysis. For normalizing the expression of the selected genes, 18S rRNA was used as the reference gene. The qRT-PCR was performed in triplicate using $100 \mathrm{ng}$ of cDNA, $300 \mathrm{mM}$ of primers, and iTaq Universal 
Table 2

Sequences of primer using in quantitative real-time PCR.

\begin{tabular}{cllll}
\hline $\begin{array}{l}\text { Primer } \\
\text { name }\end{array}$ & Primer sequence $\left(5^{\prime}-3^{\prime}\right)$ & $\begin{array}{l}\text { Target } \\
\text { gene }\end{array}$ & $\begin{array}{l}\text { Tm } \\
\left({ }^{\circ} \mathrm{C}\right)\end{array}$ & $\begin{array}{l}\text { Product } \\
\text { size (bp) }\end{array}$ \\
\hline $\begin{array}{llll}\text { 18S } \\
\text { rRNA }\end{array}$ & GTGCATGGCCGTTCTTAGTT & $\begin{array}{l}18 \mathrm{~S} \\
\text { CRAATCTCGTGTGGCTGAA }\end{array}$ & 60 & 150 \\
-F & & & & \\
18S & & & & \\
rRNA & & & & \\
-R & & IL-1 & 59 & 200 \\
IL1-F & GTCTGTCAAGGATAAGCGCTG & & 58 & \multirow{2}{*}{196} \\
IL1-R & ACTCTGGAGCTGGATGTTGA & IL-8 & 59 & \\
IL8-F & CTGTGAAGGCATGGGTGTG & & 58 & \multirow{2}{*}{200} \\
IL8-R & GATCACTTTCTTCACCCAGGG & LBP & 59 & \\
LBP-F & ACCAGAAACTGCGAGAAGGA & & 59 & \\
LBP-R & GATTGGTGGTCGGAGGTTTG & & &
\end{tabular}

SYBR Green supermix (2X) on a CFX Connect ${ }^{\mathrm{TM}}$ Real-Time PCR System (BIO-RAD, USA). Thermal cycling conditions were $95{ }^{\circ} \mathrm{C}$ for $15 \mathrm{sec}$ (denaturation), $60^{\circ} \mathrm{C}$ for $60 \mathrm{sec}$ (annealing), and $95^{\circ} \mathrm{C}$ for $15 \mathrm{sec}$ (meltcurve analysis). The relative expression of the different genes was calculated according to the $2^{-\Delta \Delta \mathrm{Ct}}$ method [41].

\subsection{Challenge test}

The $S$. agalactiae was isolated from diseased tilapia in Northern Thailand and identified, then characterized by Gram staining and biochemical test. Detailed preparation of $S$. agalactiae was described in the previous study of Van Doan, Hoseinifar, Khanongnuch, Kanpiengjai, Unban, Van Kim and Srichaiyo [42]. Briefly, S. agalactiae was cultured in Tryptic Soy Broth and incubated at $30{ }^{\circ} \mathrm{C}$ for 24 hours in a rotation shaker at a speed of $110 \mathrm{rpm}$. A sub-culture was obtained from the stock. Then, $5 \mathrm{~mL}$ of the stock solution was transferred into a $50 \mathrm{~mL}$ flask contained Tryptic Soy Broth and incubated at $30{ }^{\circ} \mathrm{C}$ for 24 hours. The sub-cultures were raised in duplicate under similar conditions for the experiment. Growth was evaluated through optical density of $560 \mathrm{~nm}$ $(0.75 \% \mathrm{NaCl}$ was used to adjust bacterium concentration). The plates were counted in the Tryptic Soy Agar, and the calibration curves were calculated by measuring the OD of each consecutive one-half dilution series, in triplicate, before determining the cell density by classic plate count methods $\left(10^{7} \mathrm{CFU} \mathrm{mL}{ }^{-1}\right.$ of $\mathrm{S}$. agalactiae $=0.8465 \mathrm{OD}+1.6187$, $\left.\mathrm{r}^{2}=0.91\right)$.

Ten fish were randomly selected from each tank to participate in the challenge test. After setup, fish were injected intraperitoneally with 0.1

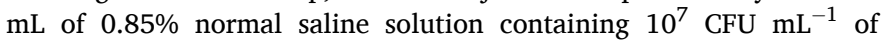
S. agalactiae as described in Wang, Gan, Cai, Wang, $\mathrm{Yu}$, Lin, $\mathrm{Lu}, \mathrm{Wu}$ and Jian [43]. Fish were monitored for disease symptoms, and dead fish were removed daily for two weeks. The relative percentage of survival (RPS) was calculated for each treatment through the following equation Amend [44]:

RPS $=(1-\%$ mortality in vaccinated $/ \%$ mortality in control $) \times 100$.

\subsection{Data analysis}

Data were processed via the SAS software program SAS [45], using one-way variance analysis (ANOVA) and Duncan's multiple range test. Different mean values $(\mathrm{P}<0.05)$ and other observations are displayed as mean \pm SD.

\section{Results}

The inclusion of PAPP over eight weeks resulted in $(P<0.05)$ an enhancement of growth variables (Table 3 ), most notably in the $10 \mathrm{~g}$ $\mathrm{kg}^{-1}$ PAPP group. No significant $(P>0.05)$ differences were observed between the 5,20 , and $40 \mathrm{~g} \mathrm{~kg}^{-1}$ PAPP groups, nor were there any statistical $(P>0.05)$ variations in survival among the PAPP groups. The PAPP-fed fish also showed greater $(P<0.05)$ FCR values, the highest being attributed to the $10 \mathrm{~g} \mathrm{~kg}^{-1}$ PAPP group (Table 3 ).

Table 4 shows the effect of the experimental diets on skin mucus lysozyme and peroxidase activities. The findings showed that dietary incorporation of PAPP resulted in increased lysozyme and peroxidase activities $(P \leq 0.05)$ after 4 and 8 weeks of feeding. The maximum rates of the skin mucus immune values were observed in the $10 \mathrm{~g} \mathrm{~kg}^{-1}$ PAPP group $(P \leq 0.05$ ); whereas fish fed a diet without the inclusion of PAPP recorded the lowest levels of lysozyme and peroxidase activities.

The impacts of PAPP on immune parameters are shown in Table 5. The results indicate that the addition of $10 \mathrm{~g} \mathrm{~kg}^{-1}$ of PAPP produced the highest levels of $(P \leq 0.05)$ of serum lysozyme, peroxidase, alternative complement, phagocytosis, and respiratory burst activities $v s$. the other treatments (Table 5). Fish fed the $0 \mathrm{~g} \mathrm{~kg}^{-1}$ and $40 \mathrm{~g} \mathrm{~kg}^{-1}$ PAPP diets recorded the lowest values of these parameters $(P \leq 0.05)$, though their differences were not statistically significant $(P \geq 0.05)$. Likewise, no significant variations were noticed between the $5 \mathrm{~g} \mathrm{~kg}^{-1}$ and $20 \mathrm{~g} \mathrm{~kg}^{-1}$ PAPP groups $(P \geq 0.05)$. The dietary inclusion of $10 \mathrm{~g} \mathrm{~kg}^{-1}$ of PAPP upregulated the IL1, IL8, and LBP gene expressions $v s$. the control and other supplemented groups (Fig. 1).

The survival rates in all PAPP diets increased $(P<0.05)$ to $63.33 \%$ (Diet 2), 76.68\% (Diet 3), 66.67\% (Diet 4), and 53.33\% (Diet 5) vs. the control (16.67\%), as shown in Fig. 2. The relative percent survival (RPS) of tilapia in Diets 2-5 were $56.00 \%, 72.00 \%, 60.00 \%$, and $44.00 \%$, respectively (Fig. 2). Fish fed $10 \mathrm{~g} \mathrm{~kg}^{-1}$ PAPP produced $(P<0.05)$ the highest RPS and highest resistance towards $S$. agalactiae (Fig. 2).

Table 3

Growth performances and feed utilization of the Nile tilapia fed different levels of dietary PAPP: Diet 1 (control), Diet 2 (5 $\mathrm{g} \mathrm{kg}^{-1}$ PAPP), Diet 3 (10 $\left.\mathrm{g} \mathrm{kg}{ }^{-1} \mathrm{PAPP}\right)$, Diet 4 $\left(20 \mathrm{~g} \mathrm{~kg}^{-1} \mathrm{PAPP}\right)$, and Diet 5 (40 $\left.\mathrm{g} \mathrm{kg}^{-1} \mathrm{PAPP}\right)$. Data assigned with different letters denote significant difference in a row $(\mathrm{P}<0.05)$.

\begin{tabular}{|c|c|c|c|c|c|}
\hline & Diet 1 & Diet 2 & Diet 3 & Diet 4 & Diet 5 \\
\hline IW (g) & $20.85 \pm 0.13$ & $20.93 \pm 0.12$ & $20.90 \pm 0.13$ & $20.87 \pm 0.12$ & $20.98 \pm 0.03$ \\
\hline \multicolumn{6}{|l|}{ FW (g) } \\
\hline 4 weeks & $61.68 \pm 0.62^{c}$ & $67.90 \pm 0.30^{b}$ & $71.51 \pm 0.66^{\mathrm{a}}$ & $68.11 \pm 0.29^{b}$ & $66.95 \pm 0.40^{\mathrm{b}}$ \\
\hline 8 weeks & $125.08 \pm 4.51^{\mathrm{c}}$ & $135.68 \pm 4.77^{\mathrm{b}}$ & $151.74 \pm 4.40^{\mathrm{a}}$ & $136.66 \pm 0.97^{\mathrm{b}}$ & $131.84 \pm 2.84^{b c}$ \\
\hline \multicolumn{6}{|l|}{ WG (g) } \\
\hline 4 weeks & $40.83 \pm 0.57^{c}$ & $46.97 \pm 0.35^{b}$ & $50.61 \pm 0.61^{\mathrm{a}}$ & $47.24 \pm 0.35^{b}$ & $45.97 \pm 0.38^{\mathrm{b}}$ \\
\hline 8 weeks & $104.23 \pm 4.51^{\mathrm{c}}$ & $114.75 \pm 4.79^{b}$ & $130.84 \pm 4.45^{\mathrm{a}}$ & $115.79 \pm 0.95^{\mathrm{b}}$ & $110.86 \pm 2.84^{b c}$ \\
\hline \multicolumn{6}{|l|}{ SGR } \\
\hline 4 weeks & $3.62 \pm 0.03^{c}$ & $3.92 \pm 0.02^{\mathrm{b}}$ & $4.10 \pm 0.02^{\mathrm{a}}$ & $3.94 \pm 0.02^{\mathrm{b}}$ & $3.87 \pm 0.02^{\mathrm{b}}$ \\
\hline 8 weeks & $2.99 \pm 0.02^{\mathrm{c}}$ & $3.11 \pm 0.06^{\mathrm{b}}$ & $3.30 \pm 0.05^{\mathrm{a}}$ & $3.13 \pm 0.01^{\mathrm{b}}$ & $3.06 \pm 0.04^{b c}$ \\
\hline \multicolumn{6}{|l|}{ FCR } \\
\hline 4 weeks & $1.19 \pm 0.01^{\mathrm{a}}$ & $1.08 \pm 0.005^{\mathrm{b}}$ & $1.04 \pm 0.008^{c}$ & $1.08 \pm 0.003^{b}$ & $1.10 \pm 0.003^{\mathrm{b}}$ \\
\hline 8 weeks & $1.29 \pm 0.01^{\mathrm{a}}$ & $1.25 \pm 0.01^{\mathrm{b}}$ & $1.21 \pm 0.01^{\mathrm{c}}$ & $1.26 \pm 0.002^{\mathrm{b}}$ & $1.26 \pm 0.01^{\mathrm{b}}$ \\
\hline \multicolumn{6}{|l|}{ SR (\%) } \\
\hline 4 weeks & 100 & 100 & 100 & 100 & 100 \\
\hline 8 weeks & $95 \pm 0.01$ & $96.68 \pm 1.44$ & $98.33 \pm 1.44$ & $96.68 \pm 1.44$ & $96.68 \pm 1.77$ \\
\hline
\end{tabular}

IW = Initial weight (g); WG = Weight gain (g); SGR = Specific growth rate (\%); FCR = Feed conversion ratio; SR = Survival rate (\%). 
Table 4

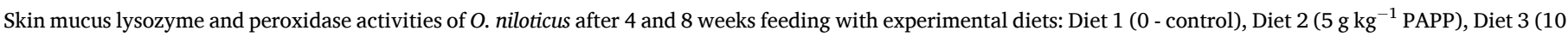
$\mathrm{g} \mathrm{kg}^{-1}$ PAPP), Diet 4 (20 $\mathrm{g} \mathrm{kg}^{-1}$ PAPP), and Diet 5 (40 $\mathrm{g} \mathrm{kg}^{-1}$ PAPP). Different letters in a row denote significant difference $(P<0.05)$.

\begin{tabular}{|c|c|c|c|c|c|c|}
\hline & & Diet 1 & Diet 2 & Diet 3 & Diet 4 & Diet 5 \\
\hline \multirow[t]{2}{*}{4 weeks } & SMLA & $1.38 \pm 0.08^{c}$ & $1.93 \pm 0.04^{\mathrm{b}}$ & $2.29 \pm 0.07^{\mathrm{a}}$ & $2.03 \pm 0.03^{b}$ & $1.50 \pm 0.07^{c}$ \\
\hline & SMPA & $0.06 \pm 0.003^{c}$ & $0.11 \pm 0.005^{\mathrm{b}}$ & $0.17 \pm 0.01^{\mathrm{a}}$ & $0.11 \pm 0.003^{b}$ & $0.08 \pm 0.005^{c}$ \\
\hline \multirow[t]{2}{*}{8 weeks } & SMLA & $2.18 \pm 0.06^{c}$ & $2.96 \pm 0.07^{\mathrm{b}}$ & $3.48 \pm 0.14^{\mathrm{a}}$ & $2.78 \pm 0.05^{\mathrm{b}}$ & $2.32 \pm 0.11^{c}$ \\
\hline & SMPA & $0.12 \pm 0.005^{c}$ & $0.18 \pm 0.005^{\mathrm{b}}$ & $0.24 \pm 0.02^{\mathrm{a}}$ & $0.16 \pm 0.008^{b}$ & $0.12 \pm 0.003^{c}$ \\
\hline
\end{tabular}

SMLA $\left(\mu \mathrm{g} \mathrm{mL}^{-1}\right)=$ Skin mucus lysozyme activity.

SMPA $\left(\mu \mathrm{g} \mathrm{mL}^{-1}\right)=$ Skin mucus peroxidase activity.

Table 5

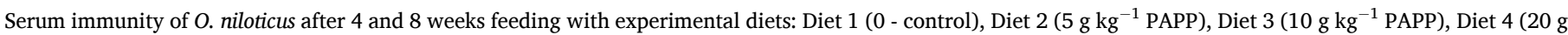
$\left.\mathrm{kg}^{-1} \mathrm{PAPP}\right)$, and Diet 5 (40 $\mathrm{g} \mathrm{kg}^{-1}$ PAPP). Different letters in a row denote significant difference $(P<0.05)$.

\begin{tabular}{|c|c|c|c|c|c|c|}
\hline & & Diet 1 & Diet 2 & Diet 3 & Diet 4 & Diet 5 \\
\hline \multirow[t]{5}{*}{4 weeks } & SL & $5.04 \pm 0.14^{\mathrm{c}}$ & $6.20 \pm 0.07^{\mathrm{b}}$ & $7.44 \pm 0.17^{\mathrm{a}}$ & $6.08 \pm 0.03^{b}$ & $5.13 \pm 0.06^{c}$ \\
\hline & SP & $0.12 \pm 0.008^{c}$ & $0.19 \pm 0.005^{\mathrm{b}}$ & $0.25 \pm 0.02^{\mathrm{a}}$ & $0.19 \pm 0.003^{b}$ & $0.16 \pm 0.006^{\mathrm{bc}}$ \\
\hline & ACH50 & $158.27 \pm 4.84^{\mathrm{c}}$ & $186.19 \pm 3.32^{\mathrm{b}}$ & $229.70 \pm 12.10^{\mathrm{a}}$ & $189.47 \pm 3.09^{\mathrm{b}}$ & $172.77 \pm 5.5^{\mathrm{bc}}$ \\
\hline & PI & $1.55 \pm 0.05^{\mathrm{c}}$ & $2.04 \pm 0.03^{\mathrm{b}}$ & $2.45 \pm 0.06^{\mathrm{a}}$ & $2.08 \pm 0.03^{\mathrm{b}}$ & $1.71 \pm 0.07^{c}$ \\
\hline & RB & $0.11 \pm 0.008^{c}$ & $0.17 \pm 0.01^{\mathrm{b}}$ & $0.22 \pm 0.009^{\mathrm{a}}$ & $0.16 \pm 0.008^{b}$ & $0.10 \pm 0.005^{c}$ \\
\hline \multirow[t]{5}{*}{8 weeks } & SL & $6.81 \pm 0.28^{c}$ & $8.20 \pm 0.08^{b}$ & $9.37 \pm 0.18^{\mathrm{a}}$ & $8.14 \pm 0.06^{\mathrm{b}}$ & $7.37 \pm 0.08^{c}$ \\
\hline & SP & $0.19 \pm 0.008^{c}$ & $0.25 \pm 0.008^{\mathrm{b}}$ & $0.31 \pm 0.01^{\mathrm{a}}$ & $0.26 \pm 0.01^{\mathrm{b}}$ & $0.21 \pm 0.008^{c}$ \\
\hline & ACH50 & $189.21 \pm 4.42^{\mathrm{c}}$ & $223.57 \pm 8.62^{\mathrm{b}}$ & $295.49 \pm 6.55^{\mathrm{a}}$ & $228.98 \pm 5.91^{\mathrm{b}}$ & $187.21 \pm 3.00^{c}$ \\
\hline & PI & $2.12 \pm 0.03^{\mathrm{c}}$ & $2.41 \pm 0.07^{\mathrm{b}}$ & $2.81 \pm 0.06^{\mathrm{a}}$ & $2.34 \pm 0.06^{\mathrm{b}}$ & $2.11 \pm 0.02^{\mathrm{c}}$ \\
\hline & RB & $0.15 \pm 0.008^{c}$ & $0.20 \pm 0.005^{\mathrm{b}}$ & $0.27 \pm 0.008^{\mathrm{a}}$ & $0.21 \pm 0.01^{\mathrm{b}}$ & $0.16 \pm 0.005^{c}$ \\
\hline
\end{tabular}

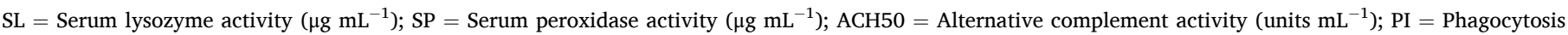
activity (bead cell ${ }^{-1}$ ); RB = Respiratory burst activity (OD655).

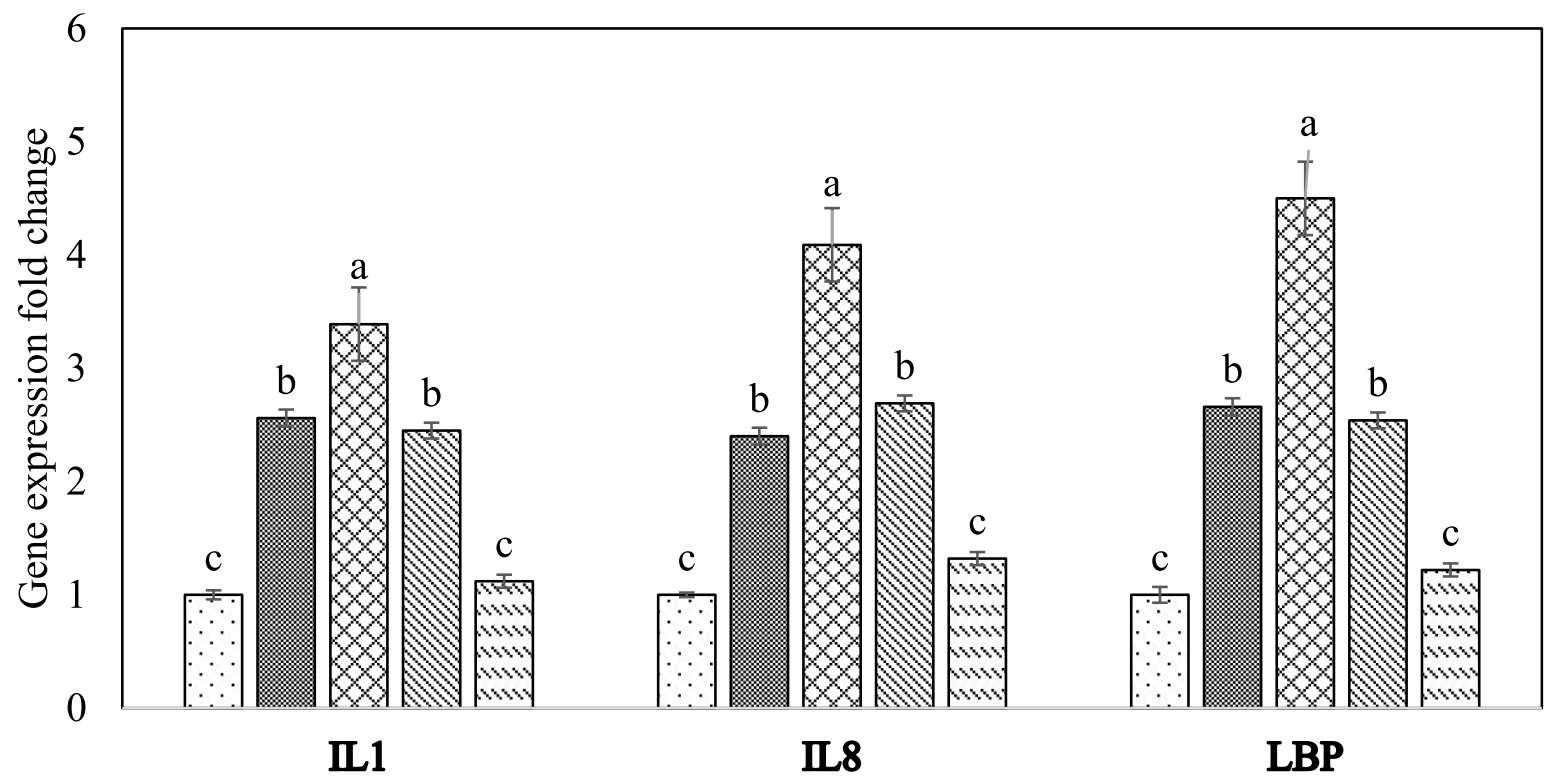

\section{$\square$ Diet 1 Diet $2 \square$ Diet 3 \& Diet 4 Diet 5}

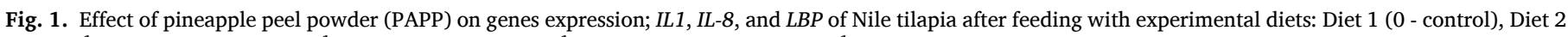

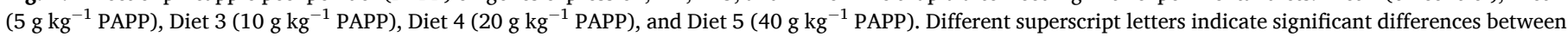
groups $(p<0.05)$.

\section{Discussion}

Utilization of agricultural by- and co-products, such as fruits and vegetables in animal feed not only reduces the environmental issues but also increases the farmers' income [46]. This practice complies with the recent legislation, which requires the food industry to find successful ways to use these residues $[47,48]$. Therefore, the present study was carried out to evaluate the effects of pineapple peel powder on growth performance, immune response, disease resistance, and relative immune gene expression of Nile tilapia.

The results indicate that growth response improved remarkably $(P \leq$ 0.05) in the PAPP groups, particularly with the fish fed the $10 \mathrm{~g} \mathrm{~kg}^{-1}$ PAPP treatment. These results parallel those of Yuangsoi, Klahan, Charoenwattanasak and Lin [49], who found that Nile tilapia fed diets containing pineapple waste extract resulted in the optimal nutrient digestibility and growth response ( $\mathrm{p} \leq 0.05)$. Wiszniewski, Jarmołowicz, Hassaan, Mohammady, Soaudy, Łuczyńska, Tońska, Terech-Majewska, Ostaszewska and Kamaszewski [50] found that Sterlet fed diets 


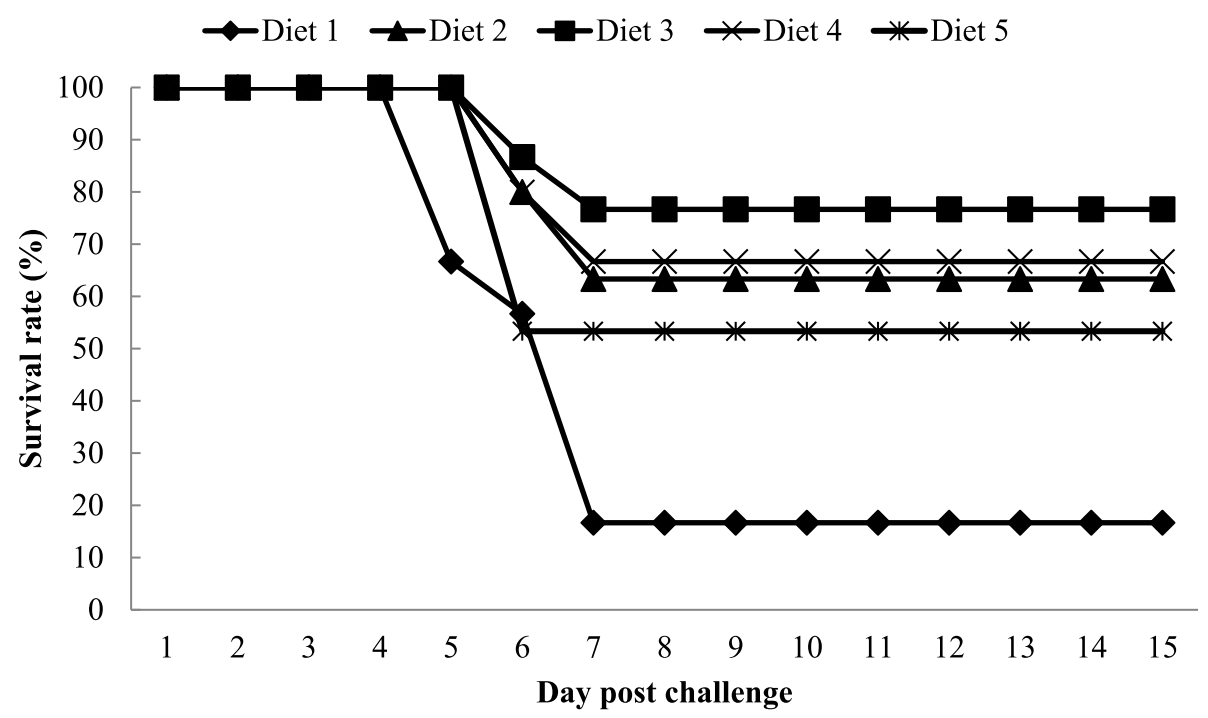

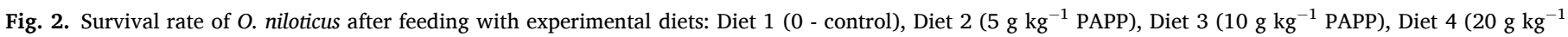
PAPP), and Diet 5 (40 $\mathrm{g} \mathrm{kg}^{-1}$ PAPP).

containing 10 and $20 \mathrm{~g} \mathrm{~kg}^{-1}$ bromelain produced the best growth rate and feed utilization. Furthermore, Deka, Sahu and Jain [51] found that the specific growth rates and protein efficiency ratios of Labeo rohita increased significantly in diets containing $25 \%$ pineapple waste. In the same context, Rahman and Yang [52] found that growth performance, weight gain, and feed conversion ratio increased significantly in chicken fed diets supplemented with leaf powder (PLP). The authors explained that the bioactive compounds present in PLP modified the gut microbiome, leading to enhanced nutrient digestion and assimilation. The present findings may be attributed to several mechanisms: i) The acceptable flavour and palatability of pineapple [53]; ii) Pineapple peel contains high amount of phenolic compounds, such as gallic acid and ferulic acid, which can improve growth performance of fish and livestock [54-57]; iii) Bromelain supplementation significantly improved villus length and mucosal folds, boosted the enzymatic activity of lipase and pepsin, and enhanced gut tissue and intestinal absorptive cells, which consequently improved nutrients absorption and digestion [50, 58,59]; iv) Pineapple chemical nutrients as carbon and other elements act as enlargement medium for the lactobacillus bacteria [60,61]. Interestingly, significantly lower growth performances were found in fish fed high dose of PAPP. Similar results were observed in rabbits fed pineapple peel [62] and pig fed pineapple by-products [63]. This may be attributable to the high fibre contents in pineapple by-products. Fibre can reduce the digestion of other dietary components, including proteins and soluble carbohydrates, that lead to the decreased digestibility and absorption of nutrients and energy [63,64]. These effects are linked to the soluble nutrient coating ability of fiber and to the physiological changes triggered by fibre diets that influence the movement and the solubility of the gut digesta, limiting the penetration of endogenous enzymes in nutrients $[65,66]$.

Improving the immune systems (innate and adaptive immune responses) has been a target goal for feed additive supplementation in aquaculture [67]. The present investigation found that dietary inclusion of pineapple peel powder (PAPP) significant enhanced skin mucus lysozyme and peroxidase activities of Nile tilapia, with the highest values observed in fish fed $10 \mathrm{~g} \mathrm{~kg}^{-1}$ PAPP. As far as we know, no current studies have evaluated the effects of PAPP on fish skin mucus immune response. However, research in similar studies has supported our results; such as the significantly enhanced mucosal immunity found in common carp, Cyprinus carpio fed orange peels derived pectin [68], convict cichlid, Amatitlania nigrofasciata fed polyphenols from agricultural by-products [69], and in rainbow trout, Oncorhynchus mykiss fed olive, Olea europea waste [70]. For serum immunity, the present study found that the dietary incorporation of PAPP significantly enhanced serum lysozyme, serum peroxidase, complement, phagocytosis, and respiratory burst activities of Nile tilapia. The results are in agreement with previous studies of African catfish, Clarias gariepinus fed doum palm fruit powder [71]; Nile tilapia, Oreochromis niloticus, and African catfish, Clarias gariepinus fed dehydrated lemon peels [72], and Nile tilapia, O. niloticus fed watermelon rind powder [73]. In terms of relative immune gene expressions, the up-regulation of $I L 1$ and $I L 8$ genes were examined in fish fed the PAPP diets, with the maximum variables found in the $10 \mathrm{~g} \mathrm{~kg}^{-1}$ PAPP fed fish. IL- $1 \beta$ and IL- 8 are essential cytokines related to a fish's immune system that facilitates the response to bacterial infections [74-76]. Similar findings were noticed in Nile tilapia, Oreochromis niloticus fed fenugreek seeds powder [77]; rohu, Labeo rohita fed banana, Musa acuminata peel flour and lemon peel enriched diet [78,79]; gilthead seabream, Sparus aurata fed dehydrated lemon peel [80], and Nile tilapia fed Withania somnifera, Nigella sativa oil and ciprofloxacin, Echinacea purpurea extract and/or vitamin C [81-83]. Lipopolysaccharide binding protein (LBP) is a soluble acute-phase protein, which plays a vital role in lipopolysaccharide signaling and non-specific immune response $[84,85]$. The LBP gene-encoded protein is linked to the acute-phase immunologic response to gram-negative pathogenic bacteria [86]. In fish, LBP can enhance innate and adaptive host's immunity $[87,88]$. In the present study, the inclusion of $10 \mathrm{~g}$ $\mathrm{kg}^{-1}$ PAPP significantly enhanced the $L B P$ gene expression of Nile tilapia. As far as we are aware, there exists no information regarding the effects of PAPP on LBP gene expression in fish. However, previous studies have suggested that LBP preserves the immunity of Crucian carp following immunization with Aeromonas hydrophila [86], and stimulates growth and immunity in Atlantic salmon [89]. While the mechanism in which PAPP stimulates immune responses in Nile tilapia has not yet been explained, it may be due to the bioactive substances present in the PAPP. Pineapple contains various compounds with pharmacological properties, such as bromelain and ferulic acid, which could stimulate immune response of fish [50,56,57]. Recently, Campos, Coscueta, Vilas-Boas, Silva, Teixeira, Pastrana and Pintado [61] demonstrated that pineapple peel powder could promote the proliferation of beneficial bacteria and production of short chain fatty acids (SCFAs) in human. SCFAs play a potential role in many cellular processes, such as gene expression, differentiation, chemotaxis, proliferation and apoptosis [90, 91]. Interestingly, higher levels of PAPP administration did not significantly affect the immune parameters. Similar results were observed in Rohu, Labeo rohita fed banana peel flour [78]. It has been reported that higher concentrations of immunostimulants supplemented for a long 
periods often lead to immunosuppression [78].

S. agalactiae seriously affects the aquaculture industry worldwide and causes vast economic damage [92]. Resistance against Streptococcus infection is a key objective in aquaculture and tilapia farming. In the present study, disease resistance improvement was also found in fish fed PAPP, with the highest value found in fish fed $10 \mathrm{~g} \mathrm{~kg}^{-1}$ PAPP. As far as we know, there is no study on the effects of PAPP on fish disease resistance. Similarly, Van Doan, Lumsangkul, Hoseinifar, Hung, Stejskal, Ring $\varnothing$, Dawood and Esteban [35] determined that the dietary administration of watermelon rind significantly increased disease resistance in Nile tilapia, $O$. niloticus. Improvement in disease resistance to Aeromonas hydrophila were also reported in barramundi, Lates calcarifer fed Citrus depressa Hayata leaf meal [93]. It was further reported that pineapple peel extract is capable of inhibiting several pathogens, such as B. cereus, $S$. aureus, $S$. typhimurium, and E. coli [94]. These findings may be due to the association of bromelain with gastrointestinal secretion signaling pathways, which include $3^{\prime}: 5^{\prime}$-cyclic monophosphatase adenosine, $3^{\prime}: 5^{\prime}$-cyclic monophosphatase guanosine, and calcium-dependent signaling cascades. Bromelain also possesses an anti-adhesive ability that prohibits microbes from adhering to different glycoprotein receptors in the gastrointestinal tract [95].

Biofloc technology plays a key role in reducing feed efficiency and enhancing the health status of aquaculture species [24,96,97]. Several studies have proven that the addition of feed additives into biofloc system could stimulate growth rate, immune response, and disease resistance $[26,35,98,99]$. Similar findings were recorded in Nile tilapia fed PAPP diets. PAPP is a good source of polyhydroxybutyrate [100], which provide a valuable addition of carbon into biofloc system [101]. Moreover, pineapple by-products exhibit probiotic properties, that can be commercially applied to new functional food formulations [14]. Kishawy, Sewid, Nada, Kamel, El-Mandrawy, Abdelhakim, El-Murr, Nahhas, Hozzein and Ibrahim [98] recorded that prebiotic inclusion to the biofloc system caused a lactic acid bacterial proliferation in the water and gastrointestinal tract, and regulated the immunity and tolerance to Aeromonas hydrophila; as well as increased the survival rate and growth of Nile tilapia. Additionally, prebiotic inclusion into the biofloc system can trigger heterotrophic bacteria to absorb the inorganic nitrogen via altering the water $\mathrm{C}: \mathrm{N}$ ratio, thereby leading to higher microbial protein production for fish and increase water quality [102, 103].

In summary, the current study has concluded that dietary treatment of PAPP produces beneficial effects on growth efficiency, disease resistance, immunity, and related gene expression of Nile tilapia culture under the biofloc system.

\section{Ethical approval}

Animal use protocol followed the guideline of Chiang Mai University (No. AQ005/2561[02/2561-10-05]).

\section{CRediT authorship contribution statement}

Hien Van Doan: Conceptualization, conducting experiment, review, and editing. Seyed Hossein Hoseinifar: Methodology. Ramasamy Harikrishnan: Data computation. Trisadee Khamlor: Gene expression, Formal analysis. Montri Punyatong: Sample collection. Wanaporn Tapingkae: Pineapple peel preparation. Morteza Yousefi: Data curation. Jorge Palma: Validation. Ehab El-Haroun: Writing - original draft.

\section{Declaration of competing interest}

No competing interests are reported.

\section{Acknowledgements}

The authors wish to thank the Thai Research Fund (Grant No. MRG6180291) for its financial assistance. This paper has been supported by the RUDN University Strategic Academic Leadership Program dedicated to Morteza Yousefi. This research work was partially supported by Chiang Mai University.

\section{References}

[1] M. Ibrahim, F. Ahmad, B. Yaqub, A. Ramzan, A. Imran, M. Afzaal, S.A. Mirza, I. Mazhar, M. Younus, Q. Akram, M.S. Ali Taseer, A. Ahmad, S. Ahmed, Chapter 4 - current trends of antimicrobials used in food animals and aquaculture, in: M. Z. Hashmi (Ed.), Antibiotics and Antimicrobial Resistance Genes in the Environment, Elsevier, 2020, pp. 39-69.

[2] L.T. Teneva, E. Schemmel, J.N. Kittinger, State of the plate: assessing present and future contribution of fisheries and aquaculture to Hawai'i's food security, Mar. Pol. 94 (2018) 28-38.

[3] FAO, The State of World Fisheries and Aquaculture 2018-Meeting the Sustainable Development Goals, FAO Rome, Italy, 2018.

[4] B.N.T. An, N.T.N. Anh, Co-culture of Nile tilapia (Oreochromis niloticus) and red seaweed (Gracilaria tenuistipitata) under different feeding rates: effects on water quality, fish growth and feed efficiency, J. Appl. Phycol. 32 (2020) 2031-2040.

[5] J. Rosa, M.F.L. Lemos, D. Crespo, M. Nunes, A. Freitas, F. Ramos, M.Â. Pardal, S. Leston, Integrated multitrophic aquaculture systems - potential risks for food safety, Trends Food Sci. Technol. 96 (2020) 79-90.

[6] S.-W. Chen, C.-H. Liu, S.-Y. Hu, Dietary administration of probiotic Paenibacillus ehimensis NPUST1 with bacteriocin-like activity improves growth performance and immunity against Aeromonas hydrophila and Streptococcus iniae in Nile tilapia (Oreochromis niloticus), Fish Shellfish Immunol. 84 (2019) 695-703.

[7] Q.F. Han, S. Zhao, X.R. Zhang, X.L. Wang, C. Song, S.G. Wang, Distribution, combined pollution and risk assessment of antibiotics in typical marine aquaculture farms surrounding the Yellow Sea, North China, Environ. Int. 138 (2020) 105551.

[8] X. Shen, G. Jin, Y. Zhao, X. Shao, Prevalence and distribution analysis of antibiotic resistance genes in a large-scale aquaculture environment, Sci. Total Environ. 711 (2020) 134626.

[9] M.R. Hasan, M.B. New, On-farm Feeding and Feed Management in Aquaculture, Food and Agriculture Organization of the United Nations Rome, 2013.

[10] E. Elferink, S. Nonhebel, H. Moll, Feeding livestock food residue and the consequences for the environmental impact of meat, J. Clean. Prod. 16 (12) (2008) 1227-1233.

[11] K. Hua, J.M. Cobcroft, A. Cole, K. Condon, D.R. Jerry, A. Mangott, C. Praeger, M. J. Vucko, C. Zeng, K. Zenger, J.M. Strugnell, The future of aquatic protein: implications for protein sources in aquaculture diets, One Earth 1 (3) (2019) 316-329.

[12] J.S. Câmara, S. Lourenço, C. Silva, A. Lopes, C. Andrade, R. Perestrelo, Exploring the potential of wine industry by-products as source of additives to improve the quality of aquafeed, Microchem. J. 155 (2020) 104758.

[13] X. Rico, B. Gullón, J.L. Alonso, R. Yáñez, Recovery of high value-added compounds from pineapple, melon, watermelon and pumpkin processing byproducts: an overview, Food Res. Int. 132 (2020) 109086.

[14] B.N.P. Sah, T. Vasiljevic, S. McKechnie, O.N. Donkor, Effect of pineapple waste powder on probiotic growth, antioxidant and antimutagenic activities of yogurt, J. Food Sci. Technol. 53 (3) (2016) 1698-1708.

[15] J. Diaz-Vela, A. Totosaus, A.E. Cruz-Guerrero, M. de Lourdes Pérez-Chabela, In vitro evaluation of the fermentation of added-value agroindustrial by-products: cactus pear (Opuntia ficus-indica L.) peel and pineapple (Ananas comosus) peel as functional ingredients, Int. J. Food Sci. Technol. 48 (7) (2013) 1460-1467.

[16] A. Freitas, M. Moldão-Martins, H.S. Costa, T.G. Albuquerque, A. Valente, A. Sanches-Silva, Effect of UV-C radiation on bioactive compounds of pineapple (Ananas comosus L. Merr.) by-products, J. Sci. Food Agric. 95 (1) (2015) 44-52.

[17] D.R. Morais, E.M. Rotta, S.C. Sargi, E.M. Schmidt, E.G. Bonafe, M.N. Eberlin, A. C. Sawaya, J.V. Visentainer, Antioxidant activity, phenolics and UPLC-ESI (-)MS of extracts from different tropical fruits parts and processed peels, Food Res. Int. 77 (2015) 392-399.

[18] A.N.M. Ramli, T.N.T. Aznan, R.M. Illias, Bromelain: from production to commercialisation, J. Sci. Food Agric. 97 (5) (2017) 1386-1395.

[19] J.A.C. Guedes, E. de Godoy Alves Filho, T.H.S. Rodrigues, M.F.S. Silva, F.V. D. Souza, L.M.A. e Silva, R.E. Alves, K.M. Canuto, E.S. de Brito, C. do Ó Pessoa, Metabolic profile and cytotoxicity of non-polar extracts of pineapple leaves and chemometric analysis of different pineapple cultivars, Ind. Crop. Prod. 124 (2018) 466-474.

[20] A. Azizan, L.A. Xin, N.A. Abdul Hamid, M. Maulidiani, A. Mediani, S.Z. Abdul Ghafar, N.K. Zulaikha Zolkeflee, F. Abas, Potentially bioactive metabolites from pineapple waste extracts and their antioxidant and $\alpha$-glucosidase inhibitory activities by 1H NMR, Foods 9 (2) (2020) 173.

[21] G. Das, J.K. Patra, T. Debnath, A. Ansari, H.-S. Shin, Investigation of antioxidant, antibacterial, antidiabetic, and cytotoxicity potential of silver nanoparticles synthesized using the outer peel extract of Ananas comosus (L.), PloS One 14 (8) (2019) e0220950-e0220950.

[22] P. Bossier, J. Ekasari, Biofloc technology application in aquaculture to support sustainable development goals, Microb. Biotechnol. 10 (5) (2017) 1012-1016. 
[23] E.G. Durigon, R. Lazzari, J. Uczay, D.L.d.A. Lopes, G.T. Jerônimo, T. Sgnaulin, M. G.C. Emerenciano, Biofloc technology (BFT): adjusting the levels of digestible protein and digestible energy in diets of nile tilapia juveniles raised in brackish water, Aquacult. Fish. (2019).

[24] M.H. Khanjani, M. Sharifinia, Biofloc technology as a promising tool to improve aquaculture production, in: Reviews in Aquaculture N/a(n/a), 2020.

[25] P. Dash, R.S. Tandel, R.A.H. Bhat, S. Mallik, N.N. Pandey, A.K. Singh, D. Sarma, The addition of probiotic bacteria to microbial floc: water quality, growth, nonspecific immune response and disease resistance of Cyprinus carpio in midHimalayan altitude, Aquaculture 495 (2018) 961-969.

[26] M.S. Rodrigues, N. Bolívar, E.C. Legarda, A.M. Guimarães, C. Guertler, C.M. do Espírito Santo, J.L.P. Mouriño, W.Q. Seiffert, D.M. Fracalossi, F. do Nascimento Vieira, Mannoprotein dietary supplementation for Pacific white shrimp raised in biofloc systems, Aquaculture 488 (2018) 90-95.

[27] H.V. Doan, S.H. Hoseinifar, P. Elumalai, S. Tongsiri, C. Chitmanat, S. Jaturasitha, S. Doolgindachbaporn, Effects of orange peels derived pectin on innate immune response, disease resistance and growth performance of Nile tilapia (Oreochromis niloticus) cultured under indoor biofloc system, Fish Shellfish Immunol. 80 (2018) $56-62$.

[28] I.H. Ahmad, A.K. Verma, A.M. Babitha Rani, G. Rathore, N. Saharan, A.H. Gora, Growth, non-specific immunity and disease resistance of Labeo rohita against Aeromonas hydrophila in biofloc systems using different carbon sources, Aquaculture 457 (2016) 61-67.

[29] NRC, Nutrient Requirements of Fish and Shrimp, The national Academies Press, Washington DC, 2011.

[30] H.V. Doan, S.H. Hoseinifar, S. Jaturasitha, M.A.O. Dawood, R. Harikrishnan, The effects of berberine powder supplementation on growth performance, skin mucus immune response, serum immunity, and disease resistance of Nile tilapia (Oreochromis niloticus) fingerlings, Aquaculture 520 (2020) 734927.

[31] Y. Avnimelech, M. Kochba, Evaluation of nitrogen uptake and excretion by tilapia in bio floc tanks, using 15N tracing, Aquaculture 287 (1) (2009) 163-168.

[32] H. Van Doan, S.H. Hoseinifar, C. Chitmanat, S. Jaturasitha, M. Paolucci, G. Ashouri, M.A.O. Dawood, M.Á. Esteban, The effects of Thai Ginseng, Boesenbergia rotunda powder on mucosal and serum immunity, disease resistance, and growth performance of Nile tilapia (Oreochromis niloticus) fingerlings, Aquaculture (2019) 734388.

[33] S. Chung, C.J. Secombes, Analysis of events occurring within teleost macrophages during the respiratory burst, Comp. Biochem. Physiol. B 89 (3) (1988) 539-544.

[34] R.M. Parry Jr., R.C. Chandan, K.M. Shahani, A rapid and sensitive assay of muramidase, in: Proceedings of the Society for Experimental Biology and Medicine vol. 119, Society for Experimental Biology and Medicine, New York, N. Y, 1965, pp. 384-386.

[35] H. Van Doan, C. Lumsangkul, S.H. Hoseinifar, T.Q. Hung, V. Stejskal, E. Ring $\varnothing$, M. A.O. Dawood, M.Á. Esteban, Administration of watermelon rind powder to Nile tilapia (Oreochromis niloticus) culture under biofloc system: effect on growth performance, innate immune response, and disease resistance, Aquaculture (2020) 735574.

[36] H. Cordero, A. Cuesta, J. Meseguer, M.A. Esteban, Changes in the levels of humoral immune activities after storage of gilthead seabream (Sparus aurata) skin mucus, Fish Shellfish Immunol. 58 (2016) 500-507.

[37] T. Yano, Assay of hemolytic complement activity, in: J.S. Stolen, T.C. Fletcher, D P. Anderson, S.C. Hattari, A.F. Rowley (Eds.), Techniques in Fish Immunology, SOS Publications, New Jersey, 1992, pp. 131-141.

[38] T. Yoshida, T. Kitao, The opsonic effect of specific immune serum on the phagocytic and chemiluminescent response in rainbow trout, Oncorhynchus mykiss phagocytes, Fish Pathol. 26 (1) (1991) 29-33.

[39] H. Van Doan, S.H. Hoseinifar, K. Sringarm, S. Jaturasitha, B. Yuangsoi, M.A. O. Dawood, M.Á. Esteban, E. Ringø, C. Faggio, Effects of Assam tea extract on growth, skin mucus, serum immunity and disease resistance of Nile tilapia (Oreochromis niloticus) against Streptococcus agalactiae, Fish Shellfish Immunol. 93 (2019) 428-435.

[40] C.J. Secombes, Isolation of salmonid macrophages and analysis of their killing activity, Tech. Fish Immunol. (1990) 137-154.

[41] K.J. Livak, T.D. Schmittgen, Analysis of relative gene expression Data using realtime quantitative PCR and the $2-\Delta \Delta C T$ method, Methods 25 (4) (2001) 402-408.

[42] H. Van Doan, S.H. Hoseinifar, C. Khanongnuch, A. Kanpiengjai, K. Unban, V. Van Kim, S. Srichaiyo, Host-associated probiotics boosted mucosal and serum immunity, disease resistance and growth performance of Nile tilapia (Oreochromis niloticus), Aquaculture 491 (2018) 94-100.

[43] B. Wang, Z. Gan, S. Cai, Z. Wang, D. Yu, Z. Lin, Y. Lu, Z. Wu, J. Jian, Comprehensive identification and profiling of Nile tilapia (Oreochromis niloticus) microRNAs response to Streptococcus agalactiae infection through highthroughput sequencing, Fish Shellfish Immunol. 54 (2016) 93-106.

[44] D.F. Amend, Potency testing of fish vaccines, Dev. Biol. Stand. 49 (1981) 8.

[45] SAS, SAS Institute Inc, SAS Campus Drive, Cary, 2003. NC USA 27513-2414.

[46] H.B. Atinkut, T. Yan, Y. Arega, M.H. Raza, Farmers' willingness-to-pay for ecofriendly agricultural waste management in Ethiopia: a contingent valuation, J. Clean. Prod. 261 (2020) 121211.

[47] N.A. Sagar, S. Pareek, S. Sharma, E.M. Yahia, M.G. Lobo, Fruit and vegetable waste: bioactive compounds, their extraction, and possible utilization, Compr. Rev. Food Sci. Food Saf. 17 (3) (2018) 512-531.

[48] M. Sillanpää, C. Ncibi, Chapter Four - circular economy in action: case studies about the transition from the linear economy in the chemical, mining, textile, agriculture, and water treatment industries, in: M. Sillanpää, C. Ncibi (Eds.), The Circular Economy, Academic Press, 2019, pp. 111-206.
[49] B. Yuangsoi, R. Klahan, S. Charoenwattanasak, S.-M. Lin, Effects of supplementation of pineapple waste extract in diet of Nile tilapia (Oreochromis niloticus) on growth, feed utilization, and nitrogen excretion, J. Appl. Aquacult. 30 (3) (2018) 227-237.

[50] G. Wiszniewski, S. Jarmołowicz, M.S. Hassaan, E.Y. Mohammady, M.R. Soaudy, J. Łuczyńska, E. Tońska, E. Terech-Majewska, T. Ostaszewska, M. Kamaszewski, The use of bromelain as a feed additive in fish diets: growth performance, intestinal morphology, digestive enzyme and immune response of juvenile Sterlet (Acipenser ruthenus), Aquacult. Nutr. 25 (6) (2019) 1289-1299.

[51] A. Deka, N. Sahu, K. Jain, Utilization of fruit processing wastes in the diet of Labeo rohita fingerling, Asian-Australas. J. Anim. Sci. 16 (11) (2003) 1661-1665.

[52] M. Rahman, D.K. Yang, Effects of Ananas comosus leaf powder on broiler performance, haematology, biochemistry, and gut microbial population, Rev. Bras. Zootec. 47 (2018).

[53] M.S. Hassaan, E.Y. Mohammady, M.R. Soaudy, H.A. El-Garhy, M.M. Moustafa, S. A. Mohamed, E.R. El-Haroun, Effect of Silybum marianum seeds as a feed additive on growth performance, serum biochemical indices, antioxidant status, and gene expression of Nile tilapia, Oreochromis niloticus (L.) fingerlings, Aquaculture 509 (2019) 178-187.

[54] L. Cai, Y.P. Li, Z.X. Wei, X.L. Li, X.R. Jiang, Effects of dietary gallic acid on growth performance, diarrhea incidence, intestinal morphology, plasma antioxidant indices, and immune response in weaned piglets, Anim. Feed Sci. Technol. 261 (2020) 114391.

[55] K.G. Samuel, J. Wang, H.Y. Yue, S.G. Wu, H.J. Zhang, Z.Y. Duan, G.H. Qi, Effects of dietary gallic acid supplementation on performance, antioxidant status, and jejunum intestinal morphology in broiler chicks, Poultry Sci. 96 (8) (2017) 2768-2775.

[56] L. Yu, H. Wen, M. Jiang, F. Wu, J. Tian, X. Lu, J. Xiao, W. Liu, Effects of ferulic acid on growth performance, immunity and antioxidant status in genetically improved farmed tilapia (Oreochromis niloticus) fed oxidized fish oil, Aquacult. Nutr. 26 (5) (2020) 1431-1442.

[57] M.A.O. Dawood, A.E.-S. Metwally, M.E. El-Sharawy, A.M. Ghozlan, H.M.R. AbdelLatif, H. Van Doan, M.A.M. Ali, The influences of ferulic acid on the growth performance, haemato-immunological responses, and immune-related genes of Nile tilapia (Oreochromis niloticus) exposed to heat stress, Aquaculture 525 (2020) 735320.

[58] P. Bowyer, E. El-Haroun, S. Davies, Dietary nucleotides enhance intestinal functional topography in European seabass (Dicentrarchus labrax), Aquacult. Res. 20 (7) (2019) 1921-1930.

[59] P. Bowyer, E. El-Haroun, H. Salim, S. Davies, Benefits of a commercial solid-state fermentation (SSF) product on growth performance, feed efficiency and gut morphology of Juvenile Nile tilapia (Oreochromis niloticus) fed different UK Lupin meal cultivars, Aquaculture (2020) 735192.

[60] M. Hassaan, M. Soltan, M. Ghonemy, Effect of synbiotics between Bacillus licheniformis and yeast extract on growth, hematological and biochemical indices of the Nile tilapia (Oreochromis niloticus), Egypt. J. Aquat. Res. 40 (2) (2014) 199-208.

[61] D.A. Campos, E.R. Coscueta, A.A. Vilas-Boas, S. Silva, J.A. Teixeira, L. M. Pastrana, M.M. Pintado, Impact of functional flours from pineapple byproducts on human intestinal microbiota, J. Funct. Foods 67 (2020) 103830.

[62] A. Aboh, G. Zoffoun, A. Djenontin, S. Babatounde, G. Mensah, Effect of graded levels of dry pineapple peel on digestibility and growth performance of rabbit, J. Appl. Biosci. 67 (2013) 5271-5276.

[63] T. Silvestre Vasconcelos, M.C. Thomaz, F.R. Castelini, P. Versuti Arantes Alvarenga, J. Alves de Oliveira, G. Ferreira Ramos, R. Keith Ono, N.C. Milani, U. dos Santos Ruiz, Evaluation of pineapple byproduct at increasing levels in heavy finishing pigs feeding, Anim. Feed Sci. Technol. 269 (2020) 114664.

[64] S.-M. Lin, C.-M. Shi, M.-M. Mu, Y.-J. Chen, L. Luo, Effect of high dietary starch levels on growth, hepatic glucose metabolism, oxidative status and immune response of juvenile largemouth bass, Micropterus salmoides, Fish Shellfish Immunol. 78 (2018) 121-126.

[65] K.B. Knudsen, The nutritional significance of "dietary fibre" analysis, Anim. Feed Sci. Technol. 90 (1-2) (2001) 3-20.

[66] M.M.L. Grundy, C.H. Edwards, A.R. Mackie, M.J. Gidley, P.J. Butterworth, P. R. Ellis, Re-evaluation of the mechanisms of dietary fibre and implications for macronutrient bioaccessibility, digestion and postprandial metabolism, Br. J. Nutr. 116 (5) (2016) 816-833.

[67] M.A.O. Dawood, S. Koshio, M.Á. Esteban, Beneficial roles of feed additives as immunostimulants in aquaculture: a review, Rev. Aquacult. 10 (4) (2018) 950-974.

[68] S.M. Hosseini, S.H. Hoseinifar, M. Mazandarani, H. Paknejad, H. Van Doan, E. R. El-Haroun, The potential benefits of orange peels derived pectin on serum and skin mucus immune parameters, antioxidant defence and growth performance in common carp (Cyprinus carpio), Fish Shellfish Immunol. 103 (2020) 17-22.

[69] S.H. Hoseinifar, M.A. Jahazi, N. Nikdehghan, H. Van Doan, M.G. Volpe, M. Paolucci, Effects of dietary polyphenols from agricultural by-products on mucosal and humoral immune and antioxidant responses of convict cichlid (Amatitlania nigrofasciata), Aquaculture 517 (2020) 734790.

[70] S.H. Hoseinifar, M. Shakouri, S. Yousefi, H. Van Doan, S. Shafiei, M. Yousefi, M. Mazandarani, M. Torfi Mozanzadeh, M.G. Tulino, C. Faggio, Humoral and skin mucosal immune parameters, intestinal immune related genes expression and antioxidant defense in rainbow trout (Oncorhynchus mykiss) fed olive (Olea europea L.) waste, Fish Shellfish Immunol. 100 (2020) 171-178.

[71] H. Al-Khalaifah, A.A. Khalil, S.A. Amer, S.I. Shalaby, H.A. Badr, M.F. Farag, D. E. Altohamy, A.N. Abdel Rahman, Effects of dietary doum palm fruit powder on 
growth, antioxidant capacity, immune response, and disease resistance of african catfish, Clarias gariepinus (B.), Animals 10 (8) (2020) 1407.

[72] A.N. Abdel Rahman, M. ElHady, S.I. Shalaby, Efficacy of the dehydrated lemon peels on the immunity, enzymatic antioxidant capacity and growth of Nile tilapia (Oreochromis niloticus) and African catfish (Clarias gariepinus), Aquaculture 505 (2019) 92-97.

[73] H.V. Doan, C. Lumsangkul, S.H. Hoseinifar, T.Q. Hung, V. Stejskal, E. Ring $\varnothing$, M.A. O. Dawood, M.Á. Esteban, Administration of watermelon rind powder to Nile tilapia (Oreochromis niloticus) culture under biofloc system: effect on growth performance, innate immune response, and disease resistance, Aquaculture 528 (2020) 735574.

[74] P.-Y. Ho, O. Byadgi, P.-C. Wang, M.-A. Tsai, L.-L. Liaw, S.-C. Chen, Identification, molecular cloning of IL- $1 \beta$ and its expression profile during nocardia seriolae infection in largemouth bass, Micropterus salmoides, Int. J. Mol. Sci. 17 (10) (2016) 1670.

[75] E. Wang, J. Wang, B. Long, K. Wang, Y. He, Q. Yang, D. Chen, Y. Geng, X. Huang, P. Ouyang, W. Lai, Molecular cloning, expression and the adjuvant effects of interleukin-8 of channel catfish (Ictalurus Punctatus) against Streptococcus iniae, Sci. Rep. 6 (1) (2016) 29310.

[76] Ü. Acar, A. Karabayır, O. Kesbiç, S. Yılmaz, F. Zemheri, Effects on some immunological parameters and gene expression levels of lupin meal (Lupinus albus) replaced with fish meal in rainbow trout (Oncorhynchus mykiss), COMU J. Agric. Facul. 6 (1) (2018) 81-89.

[77] E.M. Moustafa, M.A.O. Dawood, D.H. Assar, A.A. Omar, Z.I. Elbialy, F.A. Farrag, M. Shukry, M.M. Zayed, Modulatory effects of fenugreek seeds powder on the histopathology, oxidative status, and immune related gene expression in Nile tilapia (Oreochromis niloticus) infected with Aeromonas hydrophila, Aquaculture 515 (2020) 734589.

[78] S.S. Giri, J.W. Jun, V. Sukumaran, S.C. Park, Dietary administration of banana (Musa acuminata) peel flour affects the growth, antioxidant status, cytokine responses, and disease susceptibility of rohu, Labeo rohita, J. Immunol. Res. 2016 (2016) 4086591.

[79] R. Harikrishnan, S. Thamizharasan, G. Devi, H. Van Doan, T.T. Ajith Kumar, S. H. Hoseinifar, C. Balasundaram, Dried lemon peel enriched diet improves antioxidant activity, immune response and modulates immuno-antioxidant genes in Labeo rohita against Aeromonas sorbia, Fish Shellfish Immunol. 106 (2020) 675-684.

[80] J.M. García Beltrán, C. Espinosa, F.A. Guardiola, M.Á. Esteban, Dietary dehydrated lemon peel improves the immune but not the antioxidant status of gilthead seabream (Sparus aurata L.), Fish Shellfish Immunol. 64 (2017) 426-436.

[81] E. Zahran, M.G. El Sebaei, W. Awadin, S. Elbahnaswy, E. Risha, Y. Elseady, Withania somnifera dietary supplementation improves lipid profile, intestinal histomorphology in healthy Nile tilapia (Oreochromis niloticus), and modulates cytokines response to Streptococcus infection, Fish Shellfish Immunol. 106 (2020) $133-141$.

[82] A.N. Abdel Rahman, A.A. Khalil, H.M. Abdallah, M. ElHady, The effects of the dietary supplementation of Echinacea purpurea extract and/or vitamin C on the intestinal histomorphology, phagocytic activity, and gene expression of the Nile tilapia, Fish Shellfish Immunol. 82 (2018) 312-318.

[83] A.M. Hal, M.I. El-Barbary, Effect of Nigella sativa oil and ciprofloxacin against bacterial infection on gene expression in Nile tilapia (Oreochromis niloticus) blood, Aquaculture 532 (2021) 736071.

[84] R.R. Schumann, G. Flaggs, P. Gray, S. Wright, J. Mathison, P. Tobias, R. Ulevitch, Structure and function of lipopolysaccharide binding protein, Science 249 (4975) (1990) 1429-1431.

[85] J. Weiss, Bactericidal/permeability-increasing Protein (BPI) and Lipopolysaccharide-Binding Protein (LBP): Structure, Function and Regulation in Host Defence against Gram-Negative Bacteria, Portland Press Ltd., 2003.

[86] C.R. Raetz, C. Whitfield, Lipopolysaccharide endotoxins, Annu. Rev. Biochem. 71 (1) (2002) 635-700.
[87] G.H. Fu, F. Liu, J.H. Xia, G.H. Yue, The LBP gene and its association with resistance to Aeromonas hydrophila in tilapia, Int. J. Mol. Sci. 15 (12) (2014) 22028-22041.

[88] D. Bi, Y. Wang, Y. Gao, X. Li, Q. Chu, J. Cui, T. Xu, Recognition of lipopolysaccharide and activation of NF-kB by cytosolic sensor NOD1 in teleost fish, Front. Immunol. 9 (1413) (2018).

[89] A. Guttvik, B. Paulsen, R.A. Dalmo, S. Espelid, V. Lund, J. Bøgwald, Oral administration of lipopolysaccharide to Atlantic salmon (Salmo salar L.) fry. Uptake, distribution, influence on growth and immune stimulation, Aquaculture 214 (1-4) (2002) 35-53.

[90] A.T. Vieira, M.A.R. Vinolo, Regulation of immune cell function by short chain fatty acids and their impact on arthritis, in: Bioactive Food as Dietary Interventions for Arthritis and Related Inflammatory Diseases, Elsevier, 2019, pp. 175-188.

[91] M. Sun, W. Wu, Z. Liu, Y. Cong, Microbiota metabolite short chain fatty acids, GPCR, and inflammatory bowel diseases, J. Gastroenterol. 52 (1) (2017) 1-8.

[92] L.P. Li, R. Wang, W.W. Liang, T. Huang, Y. Huang, F.G. Luo, A.Y. Lei, M. Chen, $\mathrm{X}$. Gan, Development of live attenuated Streptococcus agalactiae vaccine for tilapia via continuous passage in vitro, Fish Shellfish Immunol. 45 (2) (2015) 955-963.

[93] Y.-L. Shiu, H.-L. Lin, C.-C. Chi, S.-P. Yeh, C.-H. Liu, Effects of hirami lemon, Citrus depressa Hayata, leaf meal in diets on the immune response and disease resistance of juvenile barramundi, Lates calcarifer (bloch), against Aeromonas hydrophila, Fish Shellfish Immunol. 55 (2016) 332-338.

[94] N. Punbasayakul, K. Samart, W. Sudmee, Antimicrobial activity of pineapple peel extract, in: Proceeding of Innovation of Functional Foods in Asia Conference, 2018.

[95] N.C. Praveen, A. Rajesh, M. Madan, V.R. Chaurasia, N.V. Hiremath, A.M. Sharma, In vitro evaluation of antibacterial efficacy of pineapple extract (bromelain) on periodontal pathogens, J. Int. Oral Health 6 (5) (2014) 96-98.

[96] G. Wei, D. Shan, G. Li, X. Li, R. Tian, J. He, Z. Shao, Prokaryotic communities vary with floc size in a biofloc-technology based aquaculture system, Aquaculture 529 (2020) 735632.

[97] M.T. Jamal, M. Broom, B.A. Al-Mur, M. Al Harbi, M. Ghandourah, A. Al Otaibi, M. F. Haque, Biofloc technology: Emerging microbial biotechnology for the improvement of aquaculture productivity, Pol. J. Microbiol. 69 (4) (2020) 401-409.

[98] A.T. Kishawy, A.H. Sewid, H.S. Nada, M.A. Kamel, S.A. El-Mandrawy, T. Abdelhakim, A.E.I. El-Murr, N.E. Nahhas, W.N. Hozzein, D. Ibrahim, Mannanoligosaccharides as a carbon source in Biofloc boost dietary plant protein and water quality, growth, immunity and Aeromonas hydrophila resistance in Nile tilapia (Oreochromis niloticus), Animals 10 (10) (2020) 1724.

[99] L.M. Laice, R.A.C. Corrêa Filho, A.S. Ventura, K.N.N. Farias, A.L.d.N. Silva, C. E. Fernandes, A.C.F. Silva, P.T.L. Barbosa, A.I. de Souza, M.G.C. Emerenciano, J. A. Povh, Use of symbiotics in biofloc (BFT)-based Nile tilapia culture: production performance, intestinal morphometry and hematological parameters, Aquaculture 530 (2021) 735715.

[100] V. Sukruansuwan, S.C. Napathorn, Use of agro-industrial residue from the canned pineapple industry for polyhydroxybutyrate production by Cupriavidus necator strain A-04, Biotechnol. Biofuels 11 (2018), 202-202.

[101] G. Luo, Z. Liu, L. Shao, H. Tan, Using poly- $\beta$-hydroxybutyric as an additional carbohydrate for biofloc in a shrimp Litopenaeus vannamei bioflocs nursery system with brackish water, Aquaculture 506 (2019) 181-187.

[102] Y. Avnimelech, Biofloc Technology: a Practical Guide Book, World Aquaculture Society, 2015.

[103] M. Emerenciano, G. Cuzon, A. Paredes, G. Gaxiola, Evaluation of biofloc technology in pink shrimp Farfantepenaeus duorarum culture: growth performance, water quality, microorganisms profile and proximate analysis of biofloc, Aquacult. Int. 21 (6) (2013) 1381-1394. 